\title{
Studies on chaetognaths off Ubatuba region, Brazil. I. Distribution and abundance
}

\author{
LIANG, Tsui Hua \& Luz Amelia VEGA-PÉREZ
}

Instituto Oceanográfico da Universidade de São Paulo

(Caixa Postal 66149, 05389-970 Sāo Paulo, SP, Brasil)

\begin{abstract}
The distribution of chaetognath species off Ubatuba region, São Paulo State, Brazil, was studied during a program of multidisciplinary research. Ten species belonging to the genera Sagitta, Krohnita and Pterosagitta were identified. $S$. enflata was the dominant species followed by $S$. friderici and $S$. hispida. The species $S$. enflata, $S$. hispida, $S$. tenuis, $S$. bipunctata and $K$. pacifica were found in the Shelf water whereas $S$. serratodentata, $S$. minima, $S$. hexaptera and $P$. draco in the Tropical water. Only $S$. friderici was found associated to Coastal water. Hydrological conditions affected population structure, size of individuals and abundance.

- Resumo: A ocorrência, distribuiçāo, freqüência dos estágios de maturidade e comprimento total do corpo das espécies do filo Chaetognatha foram estudados. As amostras foram obtidas com o auxílio de rede Bongo, nos verōes de 1985 - 1987 e invernos de 1986 e 1987, durante o Projeto "Utilização Racional do Ecossistema Costeiro da Regiāo Tropical Brasileira, Estado de São Paulon". Dez espécies foram identificadas, sendo Sagitta enflata, $S$. friderici e $S$. hispida as espécies mais abundantes. S. enflata, S. hispida, S. tenuis, S. bipunctata e Krohnita pacifica estāo associadas à água de Plataforma enquanto que $S$. serratodentata, $S$. hexaptera, $S$. minima e Pterosagitta draco à água Tropical. Apenas $S$. friderici mostrou preferência por água Costeira. Diferenças sazonais na estrutura da populaçāo, tamanho dos indivíduos, abundância e distribuiçâo estão associados à hidrodinâmica local. Nos verōes, os quetognatos apresentaram maior número de estágios maduros nas amostras examinadas, comprimentos maiores e baixa abundância como consequêencia da intrusão da água Central do Atlântico Sul que provocou uma estratificaçāo térmica característica. Em contraposiçāo, nestas amostras, nos invernos, a populaçāo é formada por indivíduos de estágios jovens, de comprimentos menores e grande abundância provavelmente resultado da mistura vertical da coluna de água e homogeneidade da estrutura térmica.
\end{abstract}

- Descriptors: Chaetognatha, Distribution, Abundance, Population structure, Ubatuba region, South Atlantic.

- Descritores: Chaetognatha, Distribuição, Abundância, estrutura da populaçāo, Ubatuba, Atlântico Sul.

\section{Introduction}

Physical factors, resource limitation and predation may affect population structure and abundance variability of a community. Planktonic organisms must be able to survive and reproduce in an environment where food, competitors, predators and potential reproducers have heterogeneous distributions (Daly \& Macaulay, 1991).
Among the plankton organisms, chaetognaths are a small and evolutionary isolated group but conspicuous in the marine plankton of all over the world (Hyman, 1959, Alvariño, 1965). They have been recognized as one of the major predators, competitors of pelagic community (Alvariño, 1985) and, recently, as an important source of particulate organic matter to deep layers (Dilling \& Aldregde, 1993).

Like most zooplankton, chaetognaths are subject to dispersing currents and changing physical-biological 
conditions. Therefore, some species become very uscful as hydrological indicators of water masses movements (Mulkana \& Mcllwain, 1973, Cheney, 1985a) and may contribute to the understanding of biogeographic processes in the sea (Andreu et al., 1989).

In this paper, the population structure, distribution and abundance of chaetognaths were studied over periodic and regular station grid surveys off the northern coast of São Paulo State.

\section{Material and methods}

This study was part of a program of multidisciplinary study of tropical ecosystems: "Brazilian Coastal Ecosystems", developed in the Ubatuba region, Sāo Paulo State, from 1985 to 1989.

Zooplankton samples studied in this work were collected on five oceanographic cruises during December 1985, 1986, 1987 and July 1986, 1987. A survey grid of 30 standard plankton stations distributed along six transects was established across the frontal region of Ubatuba, northern coast of São Paulo State $\left(24^{\circ} 10^{\prime} \mathrm{S}-44^{\circ} 30^{\prime} \mathrm{W}\right.$ and $23^{\circ} 30^{\prime} \mathrm{S}-45^{\circ} 20^{\circ} \mathrm{W}$ ) (Fig. 1).

Oblique hauls were made with a Bongo net fitted with $0.200 \mathrm{~mm}$ and $0.303 \mathrm{~mm}$ meshed nets provided with flowmeters. Samples were preserved in a seawater solution of $10 \%$ buffered formalin. In this study, 124 plankton samples obtained by the $0.303 \mathrm{~mm}$ meshed net were analysed.

Concomitantly, hydrographical data were obtained from each station by means of Nansen bottles.

In the laboratory, zooplankton samples were aliquoted with a Motoda splitter (Omori \& Ikeda, 1984). Then, chaetognaths were sorted, identified to species, examined for stage of maturity and measured under a stereoscopic microscope (Wild M7).

The identification of chaetognath species was accomplished using descriptions provided by Almeida-Prado (1961a) and Alvariño (1969). The maturity stages were identified based on Reeve's (1970):

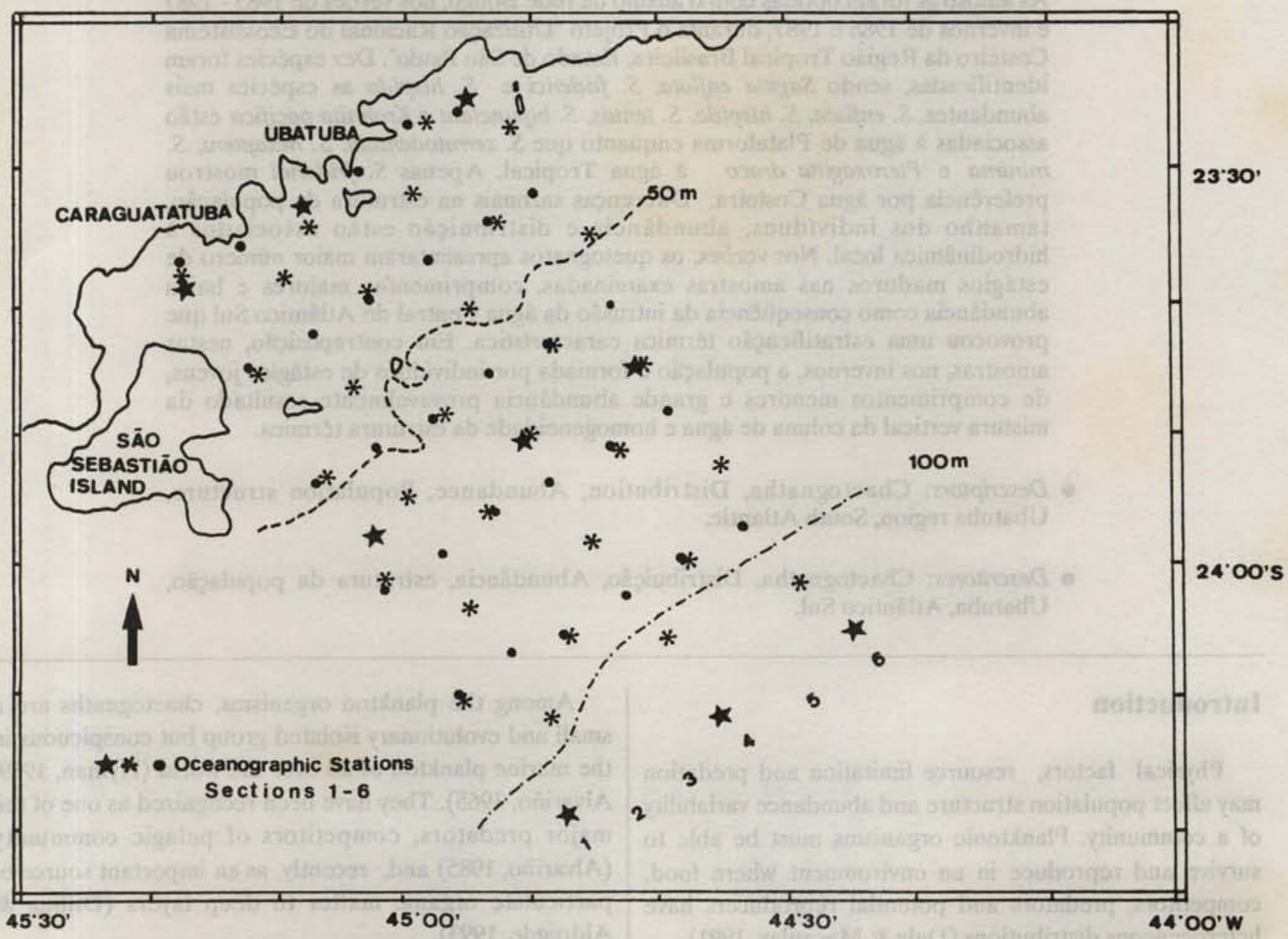

Fig. 1. Location of oceanographic stations along six perpendicular sections off northern coast of São Paulo State $\left(^{*}=\right.$ Summer 1985 and Winter 1986; $\bullet=$ Summer 1986 and Winter 1987; $\quad$ = Summer 1987). 
stage 0 (juvenile) - no gonads; stage I - gonads bcing formed; stage II - ova small and all alike in size; stage III some ova enlarged to mature size, seminal vesicles matured; stage IV - all ova enlarged. For the study of length distribution, specimens were measured from the anterior extremity of the head to the posterior segment, including the caudal fin.
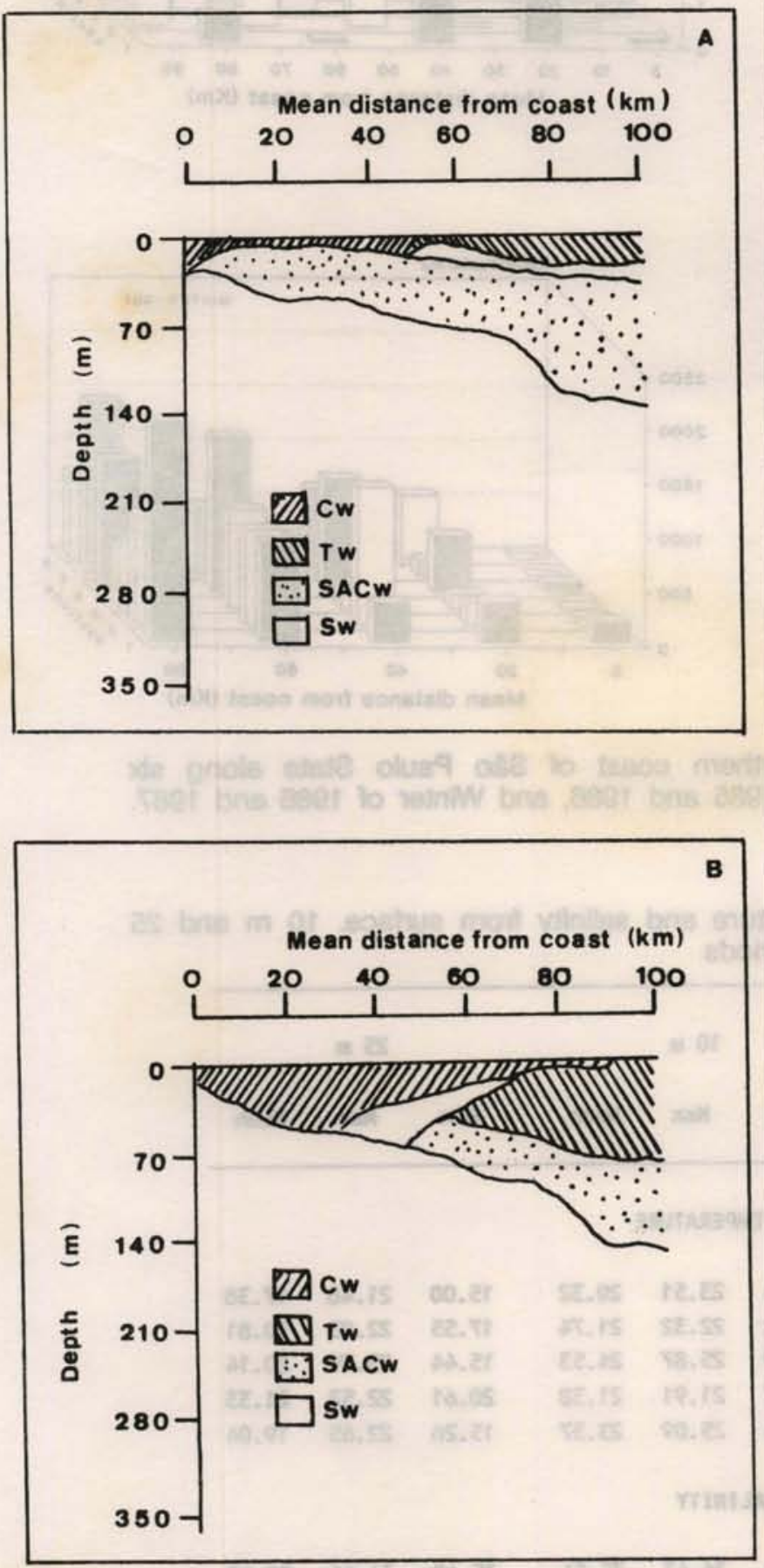

Fig. 2. Vertical distribution of water masses along a transect in the Ubatuba region. $A$ Summer; B - Winter (based on Castro Filho, 1989).
Chactognaths abundance was estimated in terms of individuals per $\mathrm{m}^{2}$ (Tanaka, 1973). Statistical analyses of length measurements were made to compare seasonal differences applying the ANOVA and the LSD test (Fisher, 1948).

\section{Hydrographic structure}

The oceanographic structure off Ubatuba, based on Castro Filho $(1987,1988,1989)$ and Castro Filho et al. (1987), is dominated by 3 water masses: Coastal water (CW), characterized by temperatures higher than $20.0^{\circ} \mathrm{C}$ and salinities lower than 35.0; Tropical water (TW) with temperature and salinity higher than $20.0^{\circ} \mathrm{C}$ and 36.0 , respectively; South Atlantic Central water (SACW) with temperature and salinity lower than $18.0^{\circ} \mathrm{C}$ and 35.0 . Shelf water (SW) is formed by mixing of SACW, TW and CW. It is characterized by temperature ranging from $20.0^{\circ} \mathrm{C}$ $23.0^{\circ} \mathrm{C}$ and salinity from $35.0-36.0$.

The water mass distribution pattern is closely related to the winds and to the influence of the Brazilian current. During Summer, the region shows two layers of vertical stratification with the presence of the thermocline. The upper layer is filled with $\mathrm{CW}$ which interacts with $\mathrm{TW}$ offshore. SACW predominates in the subsuperficial layer during this period (Fig. 2). During Winter, vertical mixing of water is generated by winds. Therefore, the water column is almost isothermal. Shelf Water constitutes a substantial fraction in this period.

\section{Results}

\section{Hydrographical data}

The temperature and salinity ranges are shown in the Table 1 for surface, $10 \mathrm{~m}$ and $25 \mathrm{~m}$. The highest values were observed in the Summer of 1986 and the lowest values were found in the Summer of 1985 . In this season, the mean temperature of the water decreased with depth while salinity increased, indicating stratification of the water column. During Winter, temperature and salinity varied little with depth, suggesting vertical mixing of water.

\section{Ocurrence and abundance}

Chaetognaths averaged from $0.69 \%$ to $6.13 \%$ of the total zooplankton collected. Table 2 shows the average, maximum and minimum values of chaetognaths in percentage by number. In general, higher densities (individuals $/ \mathrm{m}^{2}$ ) were found in the Winter surveys. 

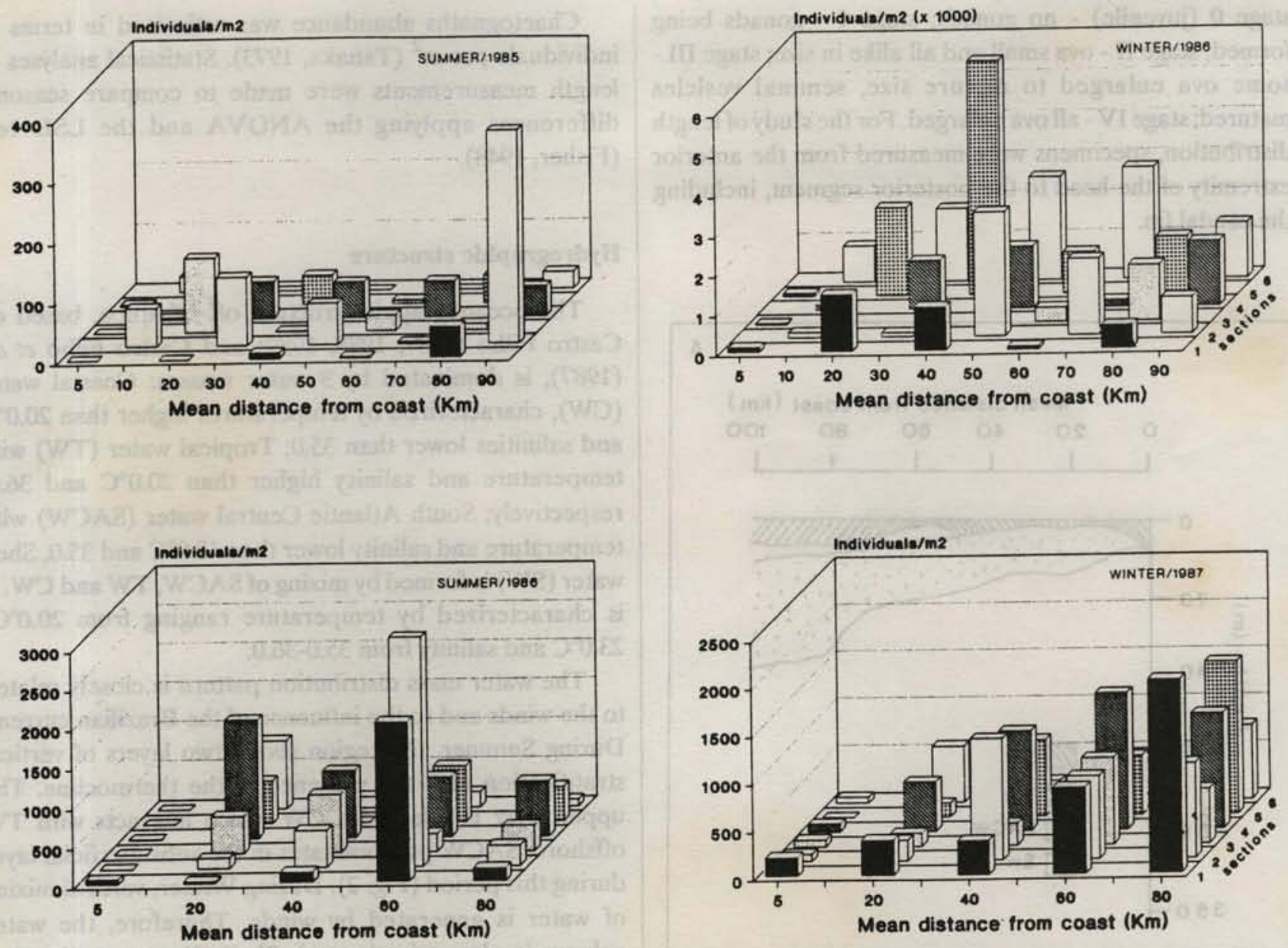

Fig. 3. Distribution of Sagitta enflata off northern coast of São Paulo State along sbx perpendicular sections during Summer of 1985 and 1986, and Winter of 1986 and 1987.

Table 1. Means and range values of temperature and salinity from surface. $10 \mathrm{~m}$ and 25 $\mathrm{m}$ depth obtained during the sampling periods

\begin{tabular}{|c|c|c|c|c|c|c|c|c|c|}
\hline Cruise & Min & $\begin{array}{l}\text { Surface } \\
\text { Max }\end{array}$ & Mean & Min & $\begin{array}{l}10 \mathrm{~m} \\
\operatorname{Max}\end{array}$ & Wean & Min & $25 \mathrm{~m}$ & Mean \\
\hline sumer/1995 & 20.55 & 23.54 & 22.51 & 15.44 & 23.51 & 20.32 & 15.00 & 21.48 & 17.38 \\
\hline Winter/1986 & 20.90 & 22.32 & 21.79 & 20.92 & 22.32 & 21.74 & 17.55 & 22.03 & 20.81 \\
\hline Sumner/1986 & 24.34 & 26.85 & 25.44 & 19.49 & 25.87 & 24.53 & 15.44 & 23.79 & 20.14 \\
\hline Winter/1987 & 20.71 & 22.50 & 21.47 & 20.47 & 21.91 & 21.38 & 20.61 & 22.52 & 21.33 \\
\hline Sumer/1987 & 23.82 & 25.46 & 24.63 & 20.24 & 25.09 & 23.37 & 15.26 & 22.65 & 19.04 \\
\hline
\end{tabular}

SALINITY

\begin{tabular}{|c|c|c|c|c|c|c|c|c|c|}
\hline summer/1985 & 35.01 & 36.11 & 35.44 & 35.09 & 36.43 & 35.54 & 35.48 & 36.61 & 35.83 \\
\hline Winter/1986 & 35.45 & 36.23 & 35.78 & 35.41 & 36.24 & 35.82 & 35.69 & 36.23 & 35.90 \\
\hline Sumer/1986 & 34.17 & 36.02 & 35.24 & 35.01 & 36.71 & 35.43 & 35.32 & 36.77 & 35.88 \\
\hline Winter/1987 & 33.49 & 35.30 & 34.47 & 33.50 & 35.50 & 34.59 & 34.49 & 36.11 & 35.07 \\
\hline sumer/1987 & 34.78 & 36.38 & 35.52 & 35.01 & 36.37 & 35.61 & 35.41 & 36.45 & 35.97 \\
\hline
\end{tabular}


Table 2. Means and range values in percentage by number of total chaetognaths collected

\begin{tabular}{c} 
Cruise Nean Range $\begin{array}{c}\text { We of } \\
\text { collections }\end{array}$ \\
\hline
\end{tabular}

\begin{tabular}{|r|l|l|r|}
\hline summer/1985 & 0.69 & $0.055-2.57$ & 27 \\
\hline Winter/1996 & 4.94 & $1.267-10.70$ & 28 \\
\hline sumner/1986 & 3.94 & $0.017-14.87$ & 30 \\
\hline Winter/1987 & 6.13 & $1.578-26.99$ & 30 \\
\hline summer/1987 & 1.31 & $0.007-2.70$ & 9
\end{tabular}

Ten chaetognath species belonging to three genera were identified in the plankton samples: Krohnita pacifica Aida, Sagitta enflata Grassi, Sagitta friderici Ritter- Zahony, Sagitta hispida Conant, Sagitta tenuis Conant, Sagitta serratodentata Krohn, Sagitta minima Grassi, Sagitta hexaptera d'Orbigny, Sagitta bipunctata Quoy \& Gaimard and Pterosagitta draco (Krohn). In this study, the species $S$. friderici and $S$. tenuis were considered two distinct species based on Almeida-Prado (1961a, b) and McLelland $(1980,1989)$.

The most abundant species were $S$. enflata, $S$. friderici and $S$. hispida whereas the less abundant and unfrequent were $S$. bipunctata, $S$. hexaptera and $P$. draco. Considerably large number of specimens of chaetognath species were found in the Winter, except $S$. friderici and S. tenuis (Table 3).

Hydrographical structure off Ubatuba region influenced the distribution of chaetognath species. Defined distribution pattern was observed in some species. High density of $S$. enflata occurred between the isobath of $50-100 \mathrm{~m}$, indicating that this species was associated to
Shelf water (Fig. 3).S. friderici concentrated near the coast where Coastal water was present (Fig. 4). The species $S$. serratodentata, $S$. hexaptera and $P$. draco were found in Tropical water (Fig. 5).

The remaining species showed a complicated distribution pattern, however seasonal abundance suggests that $S$. hispida. S. tenuis, $S$. bipunctata and $K$. pacifica were associated to Shelf water, whereas $S$. minima to Tropical water.

\section{Maturity stages}

$S$. enflata and $S$. friderici s howed different frequency distribution of maturity stages. In general, younger stages ( 0 and $\mathrm{I}$ ) were more abundant during Winter of 1986 and 1987, and Summer of 1986, whereas the older stages II and IV predominated in the Summer of 1985 and 1987. (Fig. 6)

$S$. hispida exhibited high numbers of stages 0 and I during all sampling periods, except in the Summer of 1987, when stage III dominated.

In the remaining species, stages I, II and III were observed over all the periods.

\section{Body length}

The analysis of variance showed no significant differences in the total length of the chaetognaths at stages 0 and I. At stage II, there was a significant difference between specimens lengths found in the Summer of 1985 and 1987, and the other periods. The specimen size was similar in both Summer of 1985 and 1987 surveys; and in the Winter of 1986, 1987 and Summer of 1986. Body length of stages III and IV were not compared due to the few numbers found.

Table 3. Frequency of occurrence, means of percentage by number and density (individuals $/ \mathrm{m}^{2}$ ) of chaetognath species collected

\begin{tabular}{|c|c|c|c|c|c|c|c|c|c|c|c|c|c|c|c|}
\hline \multirow[t]{2}{*}{ species } & \multicolumn{3}{|c|}{$\begin{array}{c}1985 \\
2 \text { mmer }\end{array}$} & \multicolumn{3}{|c|}{$\begin{array}{c}1986 \\
\text { Winter }\end{array}$} & \multicolumn{3}{|c|}{$\begin{array}{c}1986 \\
\text { omaer }\end{array}$} & \multicolumn{3}{|c|}{$\begin{array}{c}1987 \\
\text { Winter }\end{array}$} & \multicolumn{3}{|c|}{$\begin{array}{c}1987 \\
\text { semer }\end{array}$} \\
\hline & (F) & $(x)$ & (D) & (F) & $(x)$ & (D) & (F) & (x) & (D) & (F) & (x) & (D) & (F) & (x) & (D) \\
\hline S. enflata & 88.89 & 35.74 & 52.37 & 100.0 & 60.21 & 1285 & 90.0 & 51.47 & 563.2 & 100.0 & 65.19 & 625.3 & 100.0 & 47.54 & 703.4 \\
\hline S. friderici & 96.29 & 40.34 & 115.8 & 92.86 & 17.16 & 177.9 & 93.33 & 17.32 & 93.86 & 86.67 & 17.51 & 97.74 & 66.67 & 39.30 & 137.5 \\
\hline S. hispida & 85.18 & 12.76 & 33.39 & 100.0 & 14.25 & 223 & 96.67 & 29.28 & 246.5 & 93.33 & 9.02 & 78.17 & 88.89 & 15.78 & 57.27 \\
\hline $\boldsymbol{K}_{\text {pacifica }}$ & 29.62 & 13.74 & 36.71 & 85.71 & 8.29 & 206 & 56.67 & 4.30 & 26.83 & 80.0 & 6.61 & 52.85 & 22.22 & 11.57 & 50.57 \\
\hline S. minima & 51.85 & 6.92 & 7.27 & 57.14 & 3.75 & 65.33 & 43.33 & 3.26 & 19.09 & 80.0 & 6.18 & 69.95 & 55.55 & 9.66 & 75.43 \\
\hline$S$. tenuis & 62.96 & 12.71 & 26.74 & 10.71 & 1.50 & 26.61 & 33.33 & 3.24 & 15.04 & 6.67 & 0.47 & 5.79 & - & - & - \\
\hline S. serratodentata , & 48.15 & 9.12 & 7.63 & 3.57 & 2.2 & 23.4 & 20.0 & 13.43 & 55.69 & 13.33 & 2.37 & 17.95 & 33.33 & 7.32 & 70.18 \\
\hline$S$. bipunctata & 7.41 & 5.6 & 8.67 & 7.14 & 1.27 & 17.81 & 3.33 & 3.51 & 10.73 & $\cdot$ & $\cdot$ & - & $\cdot$ & $\bullet$ & $\cdot$ \\
\hline S. hexaptera & $\cdot$ & - & $\cdot$ & $\cdot$ & - & • & 10.0 & 2.26 & 8.88 & 3.33 & 1.02 & 11.33 & $\cdot$ & $\cdot$ & 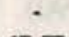 \\
\hline P. draco & $\cdot$ & $\cdot$ & - & $\cdot$ & - & • & 3.33 & 2.32 & 7.96 & 6.67 & 2.66 & 26.07 & 11.11 & 4.17 & 17.73 \\
\hline
\end{tabular}



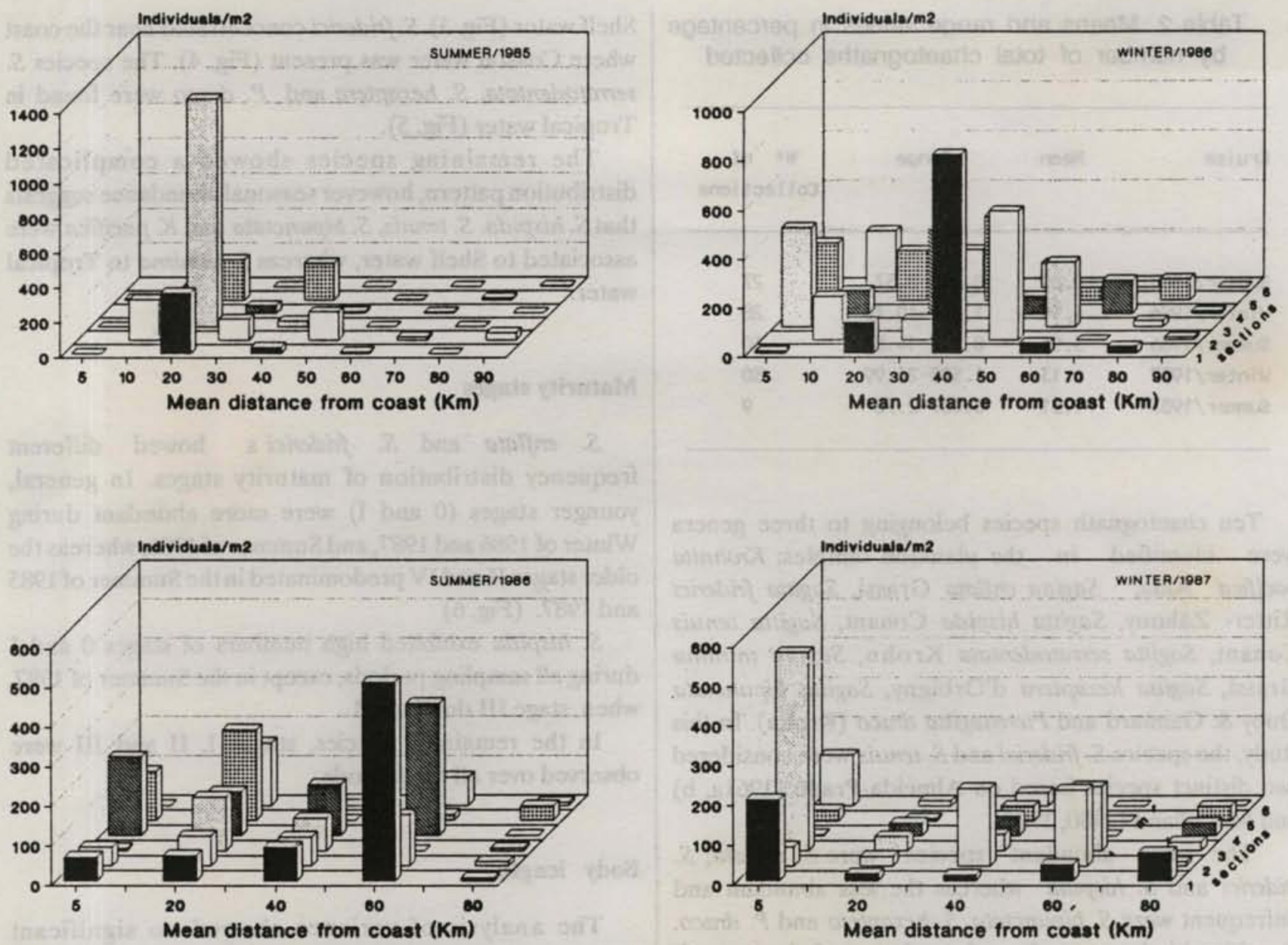

Fig. 4. Distribution of Sagitta friderici of northem coast of Săo Paulo State along six perpendicular sections during Summer of 1985 and 1986, and Winter of 1986 and 1987.

The mean length of chaetognath species at each maturity stage in the Summer and Winter is shown in the Table 4.

\section{Discussion}

In marine ecosystems, hydrodinamic events control all the biological processes in the plankton, mainly the phytoplankton production (Mann, 1991). Intense vertical stratification of the water column leads to nutrient limitation of primary production in the photic zone which may support only low production of mesozooplankton and higher trophic levels. On the other hand, vertical mixing of the water column may bring nutrients to the surface and provide suitable conditions for the growth of phytoplankton which, in turn, supports a substantial production at higher trophic levels (Kiorbe \& Nielsen, 1990). Thus, apparently high rates of mesozooplankton productivity are associated with periods or areas characterized by turbulent mixing and weak vertical stratification of the water column (Peterson \& Bellantoni, 1987).

According to Cheney (1985b), distributional patterns of chaetognaths depends closely on the changes of oceanographic structure, which is affected by the seasonal cycle of winds. In this study, we observed higher abundance of chaetognaths in the Winter, when the Ubatuba region was dominated by intense vertical mixing (Castro Filho et al., 1987). In contrast, in the Summer, the abundance of these organisms was low, probably due to the presence of vertically stratified waters caused by the intrusion of the South Atlantic Central water.

The occurrence and distribution of chaetognaths in an area is influenced by hydrological conditions, since some species are closely associated to specific water masses (Heydorn, 1959; Grant, 1991). In Ubatuba, seasonal and spatial distribution indicated that $S$. enflata, $S$. hispida, $S$. bipunctata and $\boldsymbol{K}$ pacifica were associated to Shelf water, whereas $S$. minima, $S$. hexaptera, $S$. serratodentata and $P$. draco to Tropical water. These results confirms previous findings recorded by Almeida-Prado (1961a, b, 1968) in Brazilian waters. 

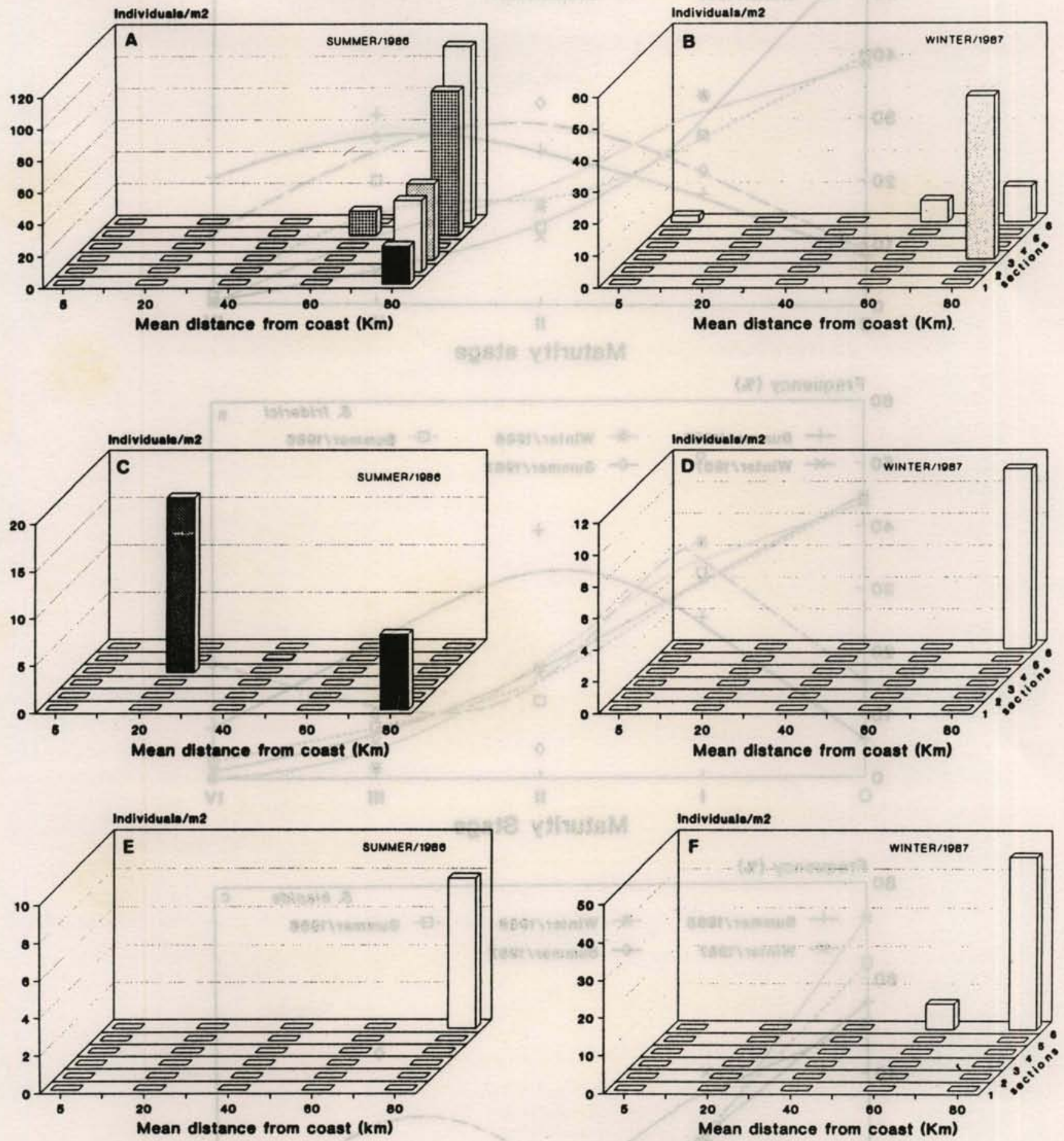

Fig. 5. Distribution of Sagitta serratodentata (A, B), S. hexaptera (C, D) and Pterosagitta draco (E, F) of northern coast of Săo Paulo State. 

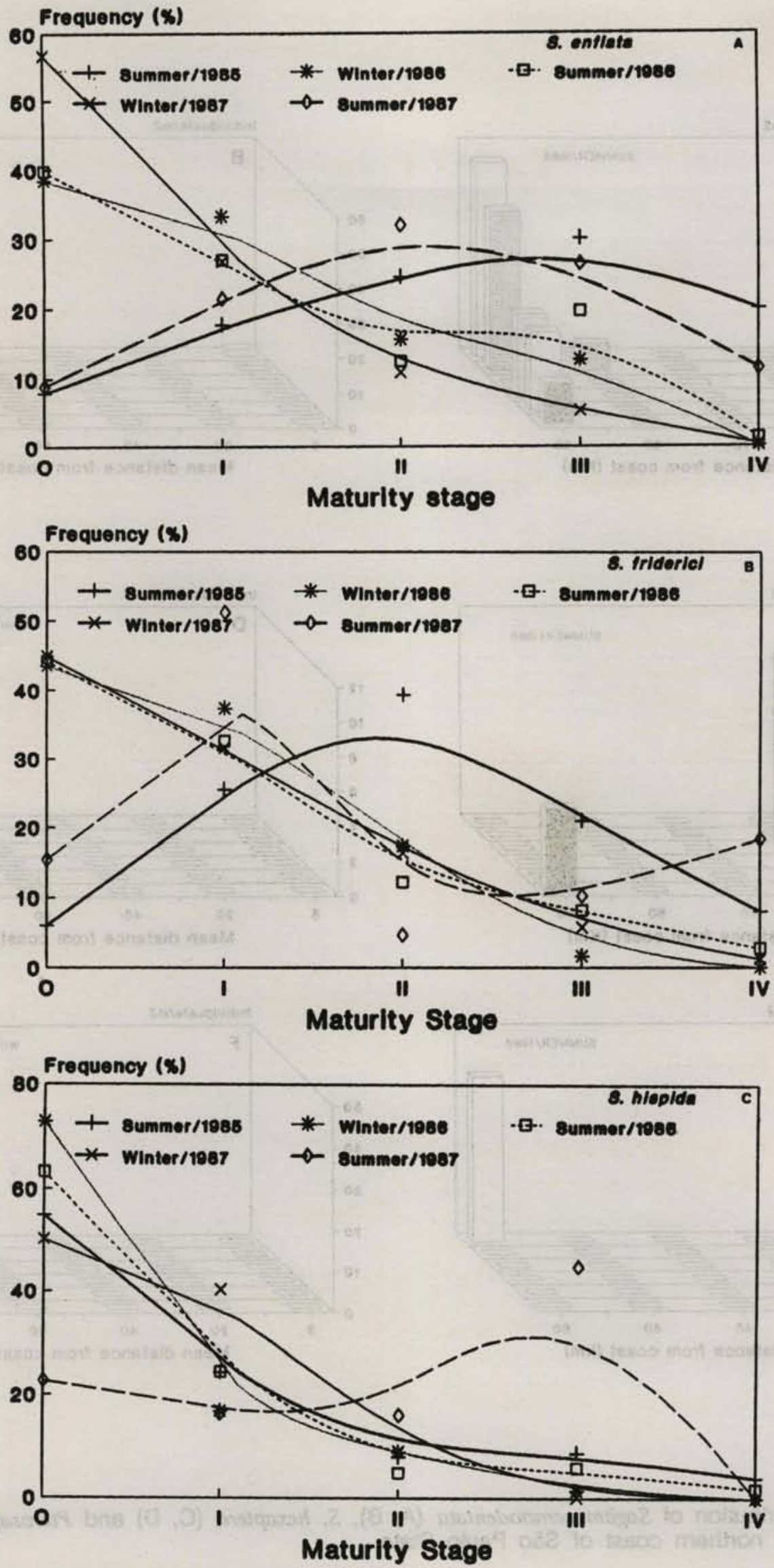

Fig. 6. Frequency distribution of maturity stage of chaetognath specles during Summer and Winter surveys. A - S. enflata; B - S. friderici; C - S. hispida. 
Table 4. Grouped means of total length $(\mathrm{mm})$ of each maturtty stage of each chetognath species collected in the Summer and Winter surveys

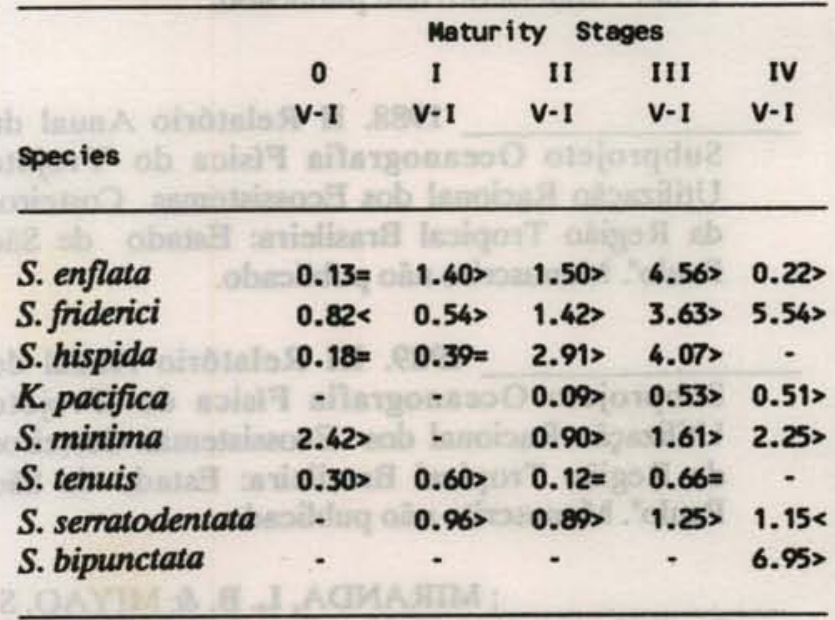

Almeida-Prado (1968) related $S$. friderici to Coastal water with temperature ranging from $21.0^{\circ} \mathrm{C}$ to $27.0^{\circ} \mathrm{C}$. However, Stone (1969) and Stuart \& Verheye (1991) characterized $S$. friderici as an indicator of a cold water mass. Recently, large numbers of $S$. friderici were recorded in a low temperature water mass off Ubatuba region by Vega-Pérez \& Liang (1992). In this study, higher numbers of $S$. friderici were found in the Summer collections suggesting that this species has affinity to the cold water mass (SACW), but is able to tolerate warmer temperatures.

$S$. tenuis is considered eurihaline preferring upper layer waters (Alvarin̄o, 1965). According to Mclelland (1984), this species shares basically the same habitat as $S$. friderici, but it likes higher salinities. Almeida-Prado (1961a) recorded $S$. tenuis in coastal and mixed waters off Ubatuba. Our findings suggest that $S$. tenuis has preference to low temperature, but it can tolerate a wide range of salinity.

On the other hand, the distribution and abundance of chaetognath species also shows a close relationship with their food (Alvariño, 1969). They are abundantly collected in areas rich in copepods, their main prey item (Pearre, 1973; Edmunds et al., 1983). In Ubatuba region, higher abundance of chaetognaths was found in the Winter and between $50-100 \mathrm{~m}$ isobaths, where the greatest quantities of copepods were also observed (Vega-Pérez, 1993).

\section{Maturity stages and individual size}

Seasonal changes of population composition have been observed in some species as $\boldsymbol{S}$. serratodentata (Bainbridge, 1963). This fact may be related to the changes of the oceanographic structure. Lough \& Trites (1989) observed higher numbers of juvenile stages of $S$. elegans in the mixed waters and adults in the weakly stratified waters of Georges Bank. We found similar results in Ubatuba region. Larger quantities of younger stages of $S$. enflata and $S$. friderici were observed in intense vertical mixed waters (Winter) and more mature stages in stratified and cold waters (Summer).

Large quantities of juvenile chaetognaths found in the plankton samples have been attributed to the mortality of adults after breeding (Owre, 1960, Reeve, 1970), vertical migration (Raymont, 1983), reproduction (Almeida-Prado, 1968, Steeman-Nielsen, 1971), sampling depth (Almeida-Prado, 1968; Gibbons, 1992) and type of net used (Stone, 1969).

According to Russel (1932a, b) the size reached by chaetognaths is conditioned among other factors by temperature. Generally, specimens that develop in the cold waters attain larger sizes than those in warmer waters (Boltovskoy, 1975). Reeve (1970) and Reeve \& Walter (1972) demonstrated in laboratory experiments that growth rate and maximum size reached by $S$. hispida depend on the temperature. Our findings show that differences of total length between Summer and Winter surveys were closely related to the temperature of the water mass.

Steeman-Nielsen (1962) hypothesized that zooplankton of rich food environments is smaller because it spends less energy searching and catching its food and allocated it to reproduction and growth. Thus, higher abundance of copepods observed during Winter (Vega-Pérez, 1993), which represent potential food to chaetognaths off Ubatuba, may influence the growth of these organisms.

Our results show that the population structure, abundance and distribution of chaetognaths depend closely on the hydrodinamic structure and presence of food.

\section{Conclusions}

1. Ten chaetognath species belonging to three genera were identified in the 124 plankton samples analized: Sagitta, Krohnita and Pterosagitta.

2. The most abundant species were Sagitta enflata, $S$. friderici and $S$. hispida.

3. In general, younger stages (0-I) were more abundant in the Winter of 1986 and 1987, whereas the older stages (II-IV) predominated in the Summer of 1985 and 1987.

4. The differences of total length observed in the Summer and Winter surveys were associated to the temperature of the water mass. 
5. Higher abundance of chactognath specimens were found in the Winter samples taken between $50-100 \mathrm{~m}$ isobaths.

6. The hydrodinamic structure off the northern coast of the Sảo Paulo State influenced the occurrence, abundance and distribution of chaetognaths.

\section{Acknowledgements}

The authors are grateful to M.Sc. C. Leng Sun and two anonymous reviewers for their critical comments on the manuscript. This research has been supported by grants from CIRM and CAPES.

\section{References}

ALMEIDA-PRADO, M. S. 1961a. Chaetognatha encontrados em águas brasileiras. Bolm Inst. oceanogr., S Paulo, 11(2):31-56.

1961b. Distribuição dos Chaetognatha no Atlântico Sul Ocidental. Bolm Inst. oceanogr., S Paulo, 11(4):15-49.

1968. Distribution and annual occurrence of Chaetognatha off Cananéia and Santos coast (Sāo Paulo, Brazil). Bolm Inst. oceanogr., S Paulo, 17(1):33-55.

ALVARIN̄O, A. 1965. Chaetognaths. Oceanogr. Mar. biol. a. Rev., 3:115-194.

1969. Los quetognatos del Atlántico: distribución y notas esenciales de sistematica. Trab. Inst. esp. Oceanogr., (37):1-290.

1985. Predation in the plankton realm, mainly with reference to fish larvae. Inv. Mar. CICIMAR, 2:1-122.

ANDREU, P. MARRASE, C. \& BERDALET, E. 1989. Distribution of epiplanktonic Chaetognatha along a transect in the Indian Ocean. J. Plankt. Res., 11(2):185-192.

BAINBRIDGE, V. 1963. Continuous plankton records: contribution towards a plankton atlas of the north Atlantic and the North Sea. Part VIII-Chaetognatha, Bull. mar. Ecol., 6(2): 40-51.

BOLTOVSKOY, D. 1975. Some biometrical, ecological, morphological and distributional aspects of Chaetognatha. Hydrobiologia, 46(4):515-534.
CASTRO FILHO, B. M. 1987. I Relatório Anual do Subprojeto Oceanografia Física do "Projeto Utilizaçāo Racional dos Ecossistemas Costeiros da Regiāo Tropical Brasileira: Estado de São Paulo". Manuscrito nāo publicado.

1988. II Relatório Anual do Subprojeto Oceanografia Física do "Projeto Utilizaçāo Racional dos Ecossistemas Costeiros da Região Tropical Brasileira: Estado de Sāo Paulo". Manuscrito nāo publicado.

1989. III Relatório Anual do Subprojeto Oceanografia Física do "Projeto Utilizaçäo Racional dos Ecossistemas Costeiros da Regiāo Tropical Brasileira: Estado de Sāo Paulo". Manuscrito não publicado.

; MIRANDA, L. B. \& MIYAO, S. Y. 1987. Condiçōes hidrográficas na plataforma continental ao largo de Ubatuba: variaçōes sazonais e em média escala. Bolm Inst. oceanogr., S Paulo, 35(2):135-151.

CHENEY, J. 1985a. Spatial and temporal abundance patterns of oceanic chaetognaths in the western North Atlantic. I. Hydrographic and seasonal abundance patterns. Deep-Sea Res., 32:1041-1059.

1985b. Spatial and temporal patterns of oceanic chaetognaths in the western North Atlantic. II. Vertical distributon and migrations. Deep-Sea Res., 32:1061-1075.

DALY, K. L \& MACAULAY, M. C. 1991. Influence of physical and biological mesoscale dynamics on the seasonal distribution and behavior of Euphausia superba in the antarctic marginal zone. Mar. Ecol.-Progr. Ser., 79:37-66.

DILLING, L. \& ALLDREDGE, A. L. 1993. Can chaetognath fecal pellets contribute significantly to carbon flux? Mar. Ecol.- Progr. Ser., 92:51-58.

EDMUNDS, P. J.; EVANS,S. M.; HUTABARAT, S. \& SOEDARSONO, P. 1983. Preliminary observations on predator/prey relationships between chaetognaths and copepods in the Java Sea. Mar. Behav. Physiol., 10:97-102.

FISHER, R. A. 1948. The Design of Experiments. Edinburgh, Oliver \& Boyd. 260p.

GRANT, G. C. 1991. Chaetognatha from the central and southern Middle Atlantic Bight. Species composition, temperature-salinity relationships, and interspecific associations. Fishery Bull, natn. mar. Fish. Serv., U.S., 89:33-40. 
HEYDORN, A. E. F. 1959. The Chactognatha off west coast of the union South Africa. Investl. Rept. Div., Sea Fish., Repub. S. Afr., 36:1-56.

GIBBONS, M. J. 1992. Diel feeding and vertical migration of Sagitta serratodentata Krohn tasmanica Thompson (Chaetognatha) in the southern Benguela. J. Plankt. Res., 14(2):249-260.

HYMAN, L . H. 1959. The invertebrates. The smaller coelomate groups. The enteroceleous coelomates phylum Chaetognatha. New York, McGraw-Hill. p. 1-71.

KIORBE, T. \& NIELSEN, T. G. 1990 . Effects of wind stress on vertical water column structure, phytoplankton growth, and productivity of planktonic copepods. In: Barnes, M. \& Gibson, R. N. eds Trophic Relationships in the Marine Environment. p. 28-40.

LOUGH, R. G. \& TRITES, R. W. 1989. Chaetognaths and oceanography on Georges Bank. J. mar. Res., 47:343-369.

MANN, K. H. 1991. Organisms and ecosystems. In: Barnes, R. S. \& Mann, K. H. eds Fundaments of aquatic ecology. Blackwell, London. p. 3-28.

MCLELLAND, J. A. 1984. Observations on the chaetognath distributions in the northeastern Gulf of Mexico during the Summer of 1974. NE Gulf Sci., 7:49-59.

MULKANA, M. S. \& MCLLWAIN, T. D. 1973. The seasonal occurrence and abundance of Chaetognatha in Mississipi Sound. Gulf Res. Repts, 4:264-271.

OMORI, M. \& IKEDA, T. 1984. Methods in marine zooplankton ecology. John Wiley \& Sons, 332 pp.

ORESLAND, V. 1987. Feeding of the chaetognaths Sagitta elegans and $S$. setosa at different seasons in Gullmarsfjorden, Sweden. Mar. Ecol.-Progr. Ser., 39:69-79.

OWRE, H. B. 1960. Plankton of Florida Current. VI. The chaetognath. Bull. mar. Sci., 10:255-322.

PEARRE Jr, S. 1973. Vertical migration and feeding in Sagitta elegans Verril. Ecology, 54:300-314.

PETERSON, W. T. \& BELLANTONI, D. C. 1987. Relationships between water-column stratification, phytoplankton cell size and copepod fecundity in long Island Sound and off Central Chile. Afr. J. mar Sci. 5:411-421.
RAKUSA-SUSZCZEWSKI, S. J. 1969. The food and feeding habits of Chaetognatha in the seas around the British Isles. Pol. Archs Hydrobiol., 16:213-232.

RAYMONT, T. E. 1983. Plankton and productivity in the oceans. Zooplankton. Oxford, Pergamon Press. v. 2. 798p.

REEVE, M. R. 1970. The biology of Chaetognatha. I. Quantitative aspects of growth and egg production in Sagitta hispida. In: Steele, J. H., ed. Marine food chains. Edinburgh, Oliver \& Boyed. p. 169-189.

\& WALTER, M. A. 1972. Conditions of culture food- size selection and the effects of temperature and salinity on growth rate and generation time in Sagitta hispida Conant. J. expl mar. Biol. Ecol., 9:191-200.

RUSSEL, F. S. 1932a. On the biology of Sagitta. The breeding and growth of Sagitta elegans Verril in the Plymouth Area, 1930-31. J. mar biol. Ass. U.K., 18:131-145.

1932b. On the biology of Sagitta. The breeding and growth of Sagitta setosa J. Müller in the Plymouth Area, 1930-31, with a comparison with that of $S$. elegans Verril. J. mar. biol. Ass. U.K., 18:147- 160.

SAMEOTO, D. D. 1971. Life history, ecosystem production and an empirical mathematical model of the population of Sagitta elegans in St. Margaret's Bay, Nova Scotia. J. Fish. Res. Bd Can., 28:971-985.

STEEMANN-NIELSEN, E. 1962. The relationship between phytoplankton and zooplankton in the sea. Rapp. P.-v. Réun. Cons. perm. int. Explor. Mer, 153:178-182.

STONE, J. H. 1969. The Chaetognatha community of the Agulhas Current, its structure and related properties. Ecol. Monogr., 39:433-463.

STUART, V. \& VERHEYE, H. M. 1991. Diel migration and feeding patterns of the chaetognath, Sagitta friderici, off the west coast of South Africa. J. mar. Res., 49:493-515.

TANAKA, S. 1973. Stock assesment by means of ichtyoplankton surveys. Fish. tech. Pap. F.A.O., 122:33-51.

VEGA-PÉREZ, L. A. 1993. Estudo do zooplâncton da região de Ubatuba, Estado de São Paulo. Publçảo esp. Inst. oceanogr., S Paulo, (10):65-84. 
VEGA-PÉREZ, L. A. \& LIANG, T. H. 1992. Feeding of a pelagic chaetognath, Sagitta friderici Ritter-Załhony off Ubatuba region (São Paulo, Brazil). Bolm Inst. oceanogr., S Paulo, 40(1/2): 93-100.

(Manuscript received 12 December 1993; revised 27 September, accepted 01 November 1994) 